\title{
Microeconomic relationships between and among fishers and traders influence the ability to respond to social-ecological changes in a small-scale fishery
}

\author{
$\underline{\text { Stuart Kininmonth }}^{1,2}$, Beatrice Crona $^{1,3}$, Örjan Bodin $^{1}, \underline{\text { Ismael Vaccaro }}^{4}, \underline{\text { Lauren J. Chapman }}^{5}$ and $^{\text {Colin A. Chapman }}{ }^{6}$
}

\begin{abstract}
Understanding the cross-scale nature of how natural resource trading links to local extraction patterns remains a topic of great relevance to stewardship and sustainable use of ecological systems. Microeconomic influences on a society's pattern of smallscale natural resources utilization can exacerbate resource overuse, especially under increased population pressure. In many rural communities that are based on a limited diversity of resource industries, quantifying the response of extractors and traders to market and environmental fluctuations is critical to understanding management constraints. We examine the fishing practices of a small lake in Uganda, East Africa, from the dual perspectives of the traders and the fishers using a Bayesian Belief Network approach based on detailed interview surveys. Fishers in this small lake target Nile perch (Lates niloticus) and Nile tilapia (Oreochromis niloticus), two fish species of high commercial and food security significance in East Africa. We combined data on financial, social, and ecological systems to understand how aspects of trading quantitatively relate to fish extraction patterns in Lake Nabugabo Uganda. Importantly, we find that the patron-client type relationships generate incentives to extract specific fish, whereas "freelancer" independent fishers are able to create responsive and flexible extraction practices that match market and environmental fluctuations. Management of fishing administered by local Beach Management Units will likely have a higher probability of success when in synchrony with trading relationships and ecological dynamics. We use this study in Uganda to reflect on methodological challenges and opportunities of combining multiple types of data sets for cross-scale analysis of social-ecological system dynamics.
\end{abstract}

Key Words: Bayesian Belief Networks; fisheries; freelancer; Nile perch; Nile tilapia; patron client; Uganda

\section{INTRODUCTION}

Conventional top down management between government regulation and fishers' extraction practices often simplifies or ignores the complex interplay of power relationships intertwined with fishing gear access, local fish trading agreements, and the pressure of distant markets (Crona et al. 2010, Ntara 2015). Understanding the cross-scale nature of how natural resource trade links to local extraction patterns remains a topic of great relevance to the stewardship and sustainable use of ecological systems (Crona and Bodin 2010, Marín and Berkes 2010, Thyresson et al. 2013, Vaccaro et al. 2013). It is especially relevant to small-scale fisheries that are often based on a "common pool" of resources that are increasingly connected to globalized trade (Eriksson et al. 2015, Wamukota et al. 2014, 2015). Within the fisheries, two key actor types can be identified; fishers are those individuals that physically extract fish, while traders are those individuals who purchase fish from fishers. These actor types are not mutually exclusive and traders may fish and vice versa. At the level of extraction, fishers are influenced by socioeconomic and ecological factors (Vaccaro et al. 2013) that often require longterm commitments. At the next level of exchange, traders seek to foster relationships that justify the investment of resources to satisfy markets. For many small-scale fisheries, trader-extraction arrangements are complicated and require sophisticated approaches to understand the implications of often subtle changes in the social-ecological system.
With increased population pressure, microeconomic influences can exacerbate declines in ecosystem services. For fisher communities with restricted access to technology and fishing gear, the capacity to adapt to environmental and ecological conditions such as drought and eutrophication is often constrained by the lending patterns of capital (Bodin and Crona 2008, Crona et al. 2010). For fishers who lack resources, patron-client relationships can be attractive alternatives, whereby fishing is supported by capital from patrons (often fish traders) but with conditions on the targeted fish species and trading options (Russell 1987, Merlijn 1989, Platteau and Nugent 1992). The practical implication is that the fishers are effectively employees of the capital lender despite having ownership of the fishing gear (Crona et al. 2010). The risk for the trader is that the fisher does not honor the agreement by absconding to another region or trading fish to individuals other than the nominated trader (Ntara 2015). As resources are exploited beyond their capacity to sustain extraction, ecosystem services will decline (Paterson and Chapman 2009, Maurice 2011). Flexibility to respond to ecological trends such as the declining fish catch can be severely limited if extractors are not in charge of their extractive practices, i.e., when the decision to fish or not, and the gears to be used, are effectively beyond their sphere of control (Crona and Bodin 2010).

Thus fishers with a single powerful patron can easily be locked into a vicious cycle of increased debt and increased fishing despite

${ }^{1}$ Stockholm Resilience Centre, Stockholm University, ${ }^{2}$ Centre for Ecological and Evolutionary Synthesis, University of Oslo, ${ }^{3}$ Global Economic Dynamics and the Biosphere, Royal Swedish Academy of Science, ${ }^{4}$ Department of Anthropology and McGill School of Environment, McGill University, Montreal, Quebec, Canada, ${ }^{5}$ Department of Biology, McGill University, Montreal, Quebec, Canada, ${ }^{6}$ Department of Anthropology, McGill University, Montreal, Quebec, Canada 
declining stocks (Platteau and Abraham 1987, Crona and Bodin 2010). However, fishers tied to multiple traders (we will refer to them as freelancers) may be less constrained and better able to respond. This hypothetically enables them to more independently determine their trading and fishing activities (Crona and Bodin 2010). Provided they have market access, the capacity of freelancers to respond to market dynamics and environmental fluctuations, especially fish population changes, can help to offset the more constrained fishing activity of the single patron-client fishers. The market is defined here as the place where fish are locally traded in an open context such as the landing sites on the shore of a lake. In situations where small rural communities are partially dependent on local surroundings for fish-based ecosystem services, the proportion of freelancer fishers could potentially influence resource exploitation patterns. In particular when the environmental conditions deteriorate, i.e., eutrophication, the flexibility to modify fishing practices, including targeting specific species and time spent fishing, could enhance socialecological system resilience (Marriott et al. 2004, Walker et al. 2004).

Quantifying the response of fishers and traders to market and environmental fluctuations is key for understanding management constraints but also for identifying areas of possible interventions for improved resource governance. This requires a multifaceted approach that encompasses social, economic, and ecological factors. Such disparate data include biomass estimates of fish catch, lending arrangements, and personal preferences of activity allotment, i.e., farming, fishing, building, and digging. Obtaining the necessary data, especially in situations where fishing and trading transactions are often not routinely recorded, typically requires the use of more qualitative approaches such as field interviews with fishers and traders. We use a Bayesian Belief Network $(\mathrm{BBN})$ approach to do this, combining various financial, social, and ecological data to understand how aspects of trading relate to fish extraction patterns in Lake Nabugabo, Uganda. BBN models provide an accepted way to handle missing data and enable the incorporation of different data types (Aguilera et al. 2011). In particular, BBN models are a useful mix of expert opinion and collected data such that predictive confidence in correlations between factors can be developed over time (Marcot et al. 2001, 2006). This modeling approach is based on a graphical representation of the probabilities of observing two or more events. The model structure contains the mathematics to describe the likelihood that one event will occur given some knowledge of another event.

We are specifically interested in exploring how the degree of flexibility among fishers potentially created by their singular or multiple ties to traders, i.e., freelancers versus patron-client fishers, affects fishing patterns in light of market or ecological changes. This will improve the understanding of the complex linkages among markets, trading actors, and ecological dynamics, which must be grasped if we hope to design governance structures that can deal with the increasingly multiscalar nature of drivers in small-scale fisheries. We examine practices from the dual perspectives of the traders and the fishers and use the Lake Nabugabo fishery because of the comprehensive data on social, economic, and ecological aspects of the lake fishery collected through interviews with both fishers and traders as well as catch assessments and fisheries-independent catch data (Vaccaro et al. 2013).

\section{METHODS}

\section{Study area}

Lake Nabugabo, the target of this study, is a small satellite lake of Lake Victoria, the largest tropical lake in the world (Fig. 1 in Vaccaro et al. 2013). Lake Nabugabo ( $5 \mathrm{~km}$ by $8 \mathrm{~km}$ with an average depth of $3.1 \mathrm{~m}$; Nyboer and Chapman 2013, Vaccaro et al. 2013), was formally a bay of Lake Victoria, cut off about 5000 years ago by an extensive swamp and sandbar (Stager et al. 2005). Nile perch (Lates niloticus), a large predatory fish, was introduced to Lake Victoria and some other lakes in the basin including Lake Nabugabo in the 1950s and 1960s to compensate for depleting commercial fisheries, and in the case of Lake Victoria, also to promote sport fishing (Balirwa et al. 2003, Pringle 2005). The rapid growth of the Nile perch population in Lake Victoria during the 1980s resulted in the rapid development of a new fishing industry and has fueled a very significant export market of approximately US\$350 million annually (Mkumbo and Marshall 2015), but also contributed (at least in part) to the decline or loss of many native fishes (reviewed in Balirwa et al. 2003, Downing et al. 2014). The loss of native fishes, and emergence of Nile perch as a dominant fish stock also occurred in Lake Nabugabo (OgutuOhwayo 1993).

The proximity to Lake Victoria extends an economic influence to Lake Nabugabo, based primarily on the trade price for the export destined Nile perch; conversely the social circumstances are significantly different in that the transient workforce that dominate the fishers role in Lake Victoria (Ntara 2015) are absent, and instead the lakeside local dwellers control the fishery (Vaccaro et al. 2013). Importantly, both the fishers and traders of Lake Nabugabo commonly identify other occupations, such as farming, to supplement their income, which is in contrast to the larger, highly organized systems observed in Lake Victoria (Ntara 2015). In addition to the introduction of Nile perch to Lake Nabugabo in 1960 and 1963, the Nile tilapia (Oreochromis niloticus) and three other tilapias (O. leucostictus, Tilapia rendalli, and $T$. zillii) were also introduced or gained access to the lake around the same time (Ogutu-Ohwayo 1993). Currently, Nile perch and Nile tilapia dominate the fishing effort $(42.2 \%$ and $30.3 \%$ in 2011; Vaccaro et al. 2013), but other native species, notably the small mukene (Rastrineobola argentea) and the lungfish (Protopterus aethiopicus) also contribute to the fishbased economy. The catch of other tilapias is very low $(<2 \%$ of fisher catch; Morgan and Chapman, unpublished data). The fishing gear of primary use is size selective gill nets and long lines, although light-fishing at night with small-mesh lampera nets is used exclusively for mukene, but incidentally includes a bycatch of juveniles of other species. The regulation of the fisheries during the time of our study was through a single Beach Management Unit (BMU) that has three nominated landing sites (Fig. 1). Fish trading is primarily conducted at the landing sites between the fishers and the fishmongers. Nile perch has declined in both body size and catch per unit effort from 1995 to 2010 (Paterson and Chapman 2009, Chrétien and Chapman 2016). This dynamic has implications for native species that shelter in the adjacent wetlands (Chapman et al. 1996, 2003, Chrétien and Chapman 2016) as well as the provision of fish protein for the local communities (Maurice 2011). 
Fig. 1. Network diagram of the traders (yellow circles) and fishers (red and green circles) that responded to the questionnaire. Freelancers (green circles) have multiple connections to the traders. Names are not shown and fishers who did not indicate a specific trader are omitted.

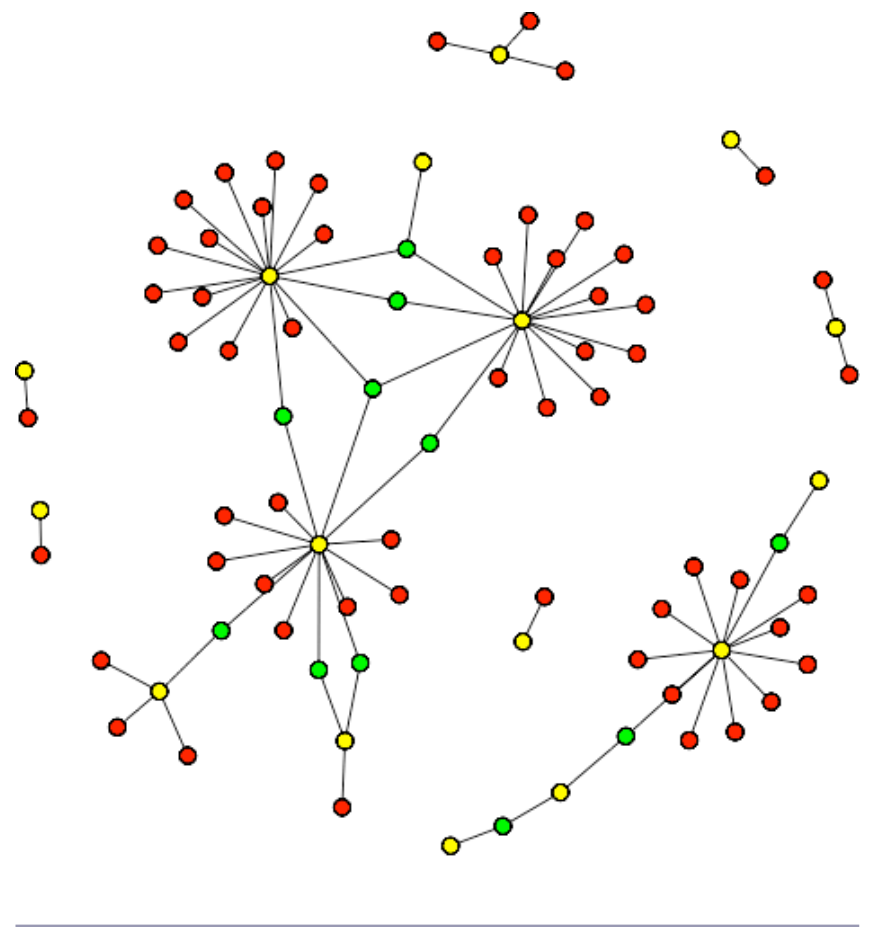

\section{Data collection}

Previous work has described the spatial structure of the fishery with a focus on fish population structures and the related fishing practices (Vaccaro et al 2013). Semistructured interviews were conducted between August 2009 and May 2010 using a 3-day recall technique. This generated a total of 245 interviews and covered a diverse range of fishing related aspects (see Vaccaro et al. 2013 for details) over 738 fishing days. The number of fishers participating was 123 , while the number of traders was 18 . A Ugandan citizen representing the National Fisheries Resources Research Institute of Uganda conducted the surveys with the support of field assistants that have worked on fisheries research in the region for several years. Table 1 details the questions posed to fishers, while Table 2 specifies the trader questions. The traders were not asked if they bought fish derived from Lake Victoria so this aspect of regional influence cannot be addressed.

\section{Network analysis}

Integral to the questionnaires was the identification of the traders used by each fisher. Fishers are identified as those individuals that physically extract fish and traders are those individuals that purchase fish from fishers. This information was then used to construct an association network where the traders and fishers were represented as nodes, and the lines indicate a relation with a trader (Fig. 1). From this basis, the trading structure of the fishers can be examined with particular relevance to the freelancer type. Fishers having a degree (number of ties/links to a trader) greater than one (freelancers) are assumed to have increased control over their trading activity, while fishers tied to only one patron trader are assumed to be largely beholden to this trader in terms of species targeted and/or gear used. The number of fishers that identify a specific trader is noted as the degree for that trader. Traders with high numbers of associated fishers are considered to be operating a dedicated fishing business rather than those traders with an agricultural focus and fishing as a sideline.

\section{Fisheries analysis through Bayesian Belief Network implementation}

Development and analysis of the fisheries BBN involves a threestage process of (i) structural development and evaluation, (ii) parameter estimation, and (iii) quantitative evaluation of scenarios (Vilizzi et al. 2012). Two BBN models were developed separately for the fishers and the trader's perspectives as reflected in the questionnaire implementation. The questionnaires were specifically tailored to explore the character of the fishers or traders activities in isolation. The questions and responses did not directly overlap, and so the BBN models were retained as separate models. The nodes in each model represent the questions posed and reflect the categorical or numerical responses. Initially a casual diagram was created from the logical understanding of the relationship between variables (Aalders 2008) to provide a structural model of the fisheries. The number of nodes in the model reflected the questionnaire design rather being trimmed to only include the nodes that are either explanatory (such as whether the fisher has agricultural interests, etc.) or response (such as species targeted and kilograms traded) variables. The mediating variables, such as market type (Table 2), help understand the inference patterns further. Linking these nodes into a coherent and logical network required expert opinion about the key correlations present in the system. Initially we developed a causal diagram and this formed the basis for the BBN structure. The linkages between nodes were reviewed to ensure simplicity because the performance of the $\mathrm{BBN}$ is optimal when connections are minimized (Marcot et al. 2006). Design guidelines from Marcot et al. (2006) were used to avoid potentially spurious or unreliable models. The model development was conducted within the Netica Version 5.15 software (Norsys https://www.norsys. com).

Two main variable types in the questionnaire were excluded from the BBN. First, details on spatial use of the lake were ignored because this aspect is adequately covered in Vaccaro et al. (2013), and the lake can be considered as a single resource pool for our analysis. Second, questions where the responses were uninformative for the model, such as sex of respondent (all male fishers and traders), were ignored. Additionally an extra node was added to each BBN to describe the local network configuration (from Fig. 1) of the fisher or trader. Fishers connected to more than one trader were designated freelancers. Patron-client traders are defined here as having at least 6 to 20 fishers identifying them as the purchaser of the fish catch.

Parameter estimation of the marginal probabilities describing the likelihood of observing any particular state for a node were then calculated using the questionnaire data within an expectation maximization learning algorithm that is able to compensate for missing values (Korb and Nicholson 2010). To evaluate the BBNs, we used a sensitivity analysis and a prediction evaluation method. 
Table 1. Fisher's questions used for the Bayesian Belief Network (BBN) and the discretization of the answers.

\begin{tabular}{|c|c|c|}
\hline Question (English translation) & BBN node & Discretization \\
\hline $\begin{array}{l}\text { What gear do you use? Translated to Active or } \\
\text { Passive fishing gear }\end{array}$ & Fishing style & Categorical: Passive, Active \\
\hline What is your main economic activity? & Fishing, digging, building, farming & $\begin{array}{l}\% \text { Time: fishing }[10-50,50,50-100] \text {, farming }[0 \text {, } \\
0-50,50-90] \text {, digging, building }[0,0-50,50] ; \text { the } \\
\text { bins have approximately }(20 \% \text { rounding) equal } \\
\text { amounts of data samples. }\end{array}$ \\
\hline What is the main gear you use? & Gear & $\begin{array}{l}\text { Categorical: gillnet, hook, mukene net, beach } \\
\text { seine }\end{array}$ \\
\hline What fish types are actually caught the most? & Primary fish species, Secondary fish species & $\begin{array}{l}\text { Categorical: NP (Nile perch), T (Nile tilapia), H } \\
\text { (haps), Ma (mamba), Mu (mukene), Sch } \\
\text { (Schilbe), Ot (other) }\end{array}$ \\
\hline For how long [did you fish today]? & $\begin{array}{l}\text { Time spent on Nile tilapia, Time spent on Nile } \\
\text { perch }\end{array}$ & $\begin{array}{l}\text { Hours: T }[0-4,4-8,8-24 \mathrm{hr}], \mathrm{NP}[0-6,6-8,8-24 \\
\text { hr]; the bins have approximately ( } 20 \% \text { rounding) } \\
\text { equal amounts of data samples. }\end{array}$ \\
\hline Do you fish alone or as part of a crew? & Operation & Categorical: alone, crew \\
\hline $\begin{array}{l}\text { How much of the fish goes to household } \\
\text { consumption/market/other? }\end{array}$ & $\begin{array}{l}\text { Fished for trader to buy, Fished for house } \\
\text { consumption, Fished for other reasons }\end{array}$ & $\begin{array}{l}\% \text { kg: Trader }[0-75,75,75-100] \text {, House }[0,0-25 \text {, } \\
25-100] \text {, Other }[0,0-80,80-100] \text {; the bins have } \\
\text { approximately ( } 20 \% \text { rounding) equal amounts of } \\
\text { data samples. }\end{array}$ \\
\hline $\begin{array}{l}\text { Do you have an agreement with this [named] } \\
\text { trader? }\end{array}$ & Agreement type & $\begin{array}{l}\text { Categorical: must, guarantees, fixed price, fuel } \\
\text { and bait, owner, other, no agreement. }\end{array}$ \\
\hline Why catch these species? & Why these species? & $\begin{array}{l}\text { Categorical: value, abundance, available, market, } \\
\text { gear, other }\end{array}$ \\
\hline
\end{tabular}

Table 2. Trader's questions used in Bayesian Belief Network (BBN) and the discretization for Figure 4.

\begin{tabular}{|c|c|c|}
\hline Question (English translation) & BBN Node & Discretization \\
\hline Where do you buy your fish? & Landing & $\begin{array}{l}\text { Categorical: Luwafu, Kituti, Kaziru, see Figure } 1 \\
\text { in Vaccaro et al. (2013) }\end{array}$ \\
\hline What is your main economic activity? & Trader Main activity, Trader Second activity & $\begin{array}{l}\text { Categorical: Farming, Trading, Fishing, } \\
\text { Cultivation, Other }\end{array}$ \\
\hline How do people pay back? & Pay back type & Categorical: Money, Fish, Other goods \\
\hline How much do you usually lend? & Loan amounts & $\begin{array}{l}\text { Ugandan Shilling: } 0 \text { to } 40,000,40,000 \text { to } 80,000 \text {, } \\
80,000 \text { to } 200,000 \text {. Note } 1 \text { Shilling }=0.00035 \text { US } \\
\text { Dollar; the bins have approximately }(20 \% \\
\text { rounding) equal amounts of data samples. }\end{array}$ \\
\hline What type of capital? & Type of capital & Categorical: Money, Boats, All above \\
\hline Why do they always sell to you? & Why buy from this fisher & $\begin{array}{l}\text { Categorical: Puts in money, Loans money/ } \\
\text { equipment, Owns boat, Established relationship, } \\
\text { Other }\end{array}$ \\
\hline $\begin{array}{l}\text { Name the markets you most commonly sell the } \\
\text { majority of your fish to. }\end{array}$ & Market type & $\begin{array}{l}\text { Categorical: Hawker, Village, Lambu factory, } \\
\text { Kakyanga factory, other }\end{array}$ \\
\hline Why this [Specified] market? & Why this market & $\begin{array}{l}\text { Categorical: Get little fish, Market, Factory, } \\
\text { Home }\end{array}$ \\
\hline $\begin{array}{l}\text { Does the prices you get when selling the fish } \\
\text { fluctuate over the year? Why? }\end{array}$ & Price fluctuations & $\begin{array}{l}\text { Categorical: Market, Customer finances, } \\
\text { Agricultural harvest, Fish supply }\end{array}$ \\
\hline How much do you buy and sell? & Amount bought $\mathrm{Kg}$ & $\begin{array}{l}\text { Kg: } 2 \text { to } 7,7 \text { to } 20,20 \text { to } 70 \text {; the bins have } \\
\text { approximately ( } 20 \% \text { rounding) equal amounts of } \\
\text { data samples }\end{array}$ \\
\hline Do you prefer some species over others? & Main target species, Secondary target species & Categorical: NP, T, Mu, Ma \\
\hline Explain why? & Why this species & $\begin{array}{l}\text { Categorical: Market suitable, Value, Frying, } \\
\text { Factory suitable, Other }\end{array}$ \\
\hline
\end{tabular}


The prediction accuracy of the fisher BBN for the "Primary fish species" node was tested through the independent evaluation of a 20\% randomly excluded dataset (49 responses). The confusion matrix showing the distribution between predicted (based on the findings at other nodes) and observed, produced an error rate of $26 \%$. A logarithmic loss value of 0.52 was calculated using the natural $\log$. These values are generally between 0 and infinity inclusive, with zero indicating the best performance. We calculated a quadratic loss value of 0.33 (also known as the Brier score). This score is generally between 0 and 2, with 0 being best. Finally, we calculated a spherical payoff of 0.80 . This payoff score is limited to the range between 0 and 1 , with 1 being best. Overall the model appears robust with a high degree of prediction capacity. Similar tests were conducted on the "Time spent on Nile perch" node. The confusion matrix has three classes of hours against which the 49 independent responses were evaluated. The fisher BBN gave an overall error rate of $25 \%$ for the predicted values of this node. The sensitivity of any specified target node to single changes in all other nodes was used to gauge the major influences in the model structure. This sensitivity is generally measured as a variance reduction for continuous nodes and entropy reduction for categorical nodes. High values indicate that the findings at one node will have a high change in the beliefs of the target node and consequently highlight the parts of the model that are most informative to the target node. To test the BBN's capacity to predict a random $20 \%$ of the questionnaire, data were withheld while constructing the marginal probability tables. This small data set was then used to explore the predictability accuracy of the BBN model (Pollino et al. 2007). The final BBN models included all data, since the number of questionnaires was limited.

\section{Patron-client and freelancer scenario evaluation}

The two BBNs were then used to predict changes in fish catch composition and fish trading volume given changes in the microeconomic relational structures between fishers and traders. Given the different perspectives captured by the two models, the impacts of the patron-client and freelancer relationships were assessed as scenarios. Scenarios provide a focused method of describing changes in model variables (Stelzenmüller et al. 2010, Gudimov et al. 2012). Each scenario (Table 3) describes the situation where a select group of nodes is given a particular state reflecting the relationship type within the fisher or trader perspective BBN models. For example, the case of the patronclient relationship is expressed in the trader BBN as $100 \%$ likelihood of trading for the main activity, a degree index of 6 to 20 , and a selection of fisher clients based on a $50 \%$ split between putting in money and lending money or equipment nodes. The selection of nodes and associated posterior likelihoods used for each scenario were developed following examination of archetypal cases identified from the network analysis. All other nodes in the BBN model were then recalculated to infer the likelihood of finding each node's state given the specified findings of the selected nodes stipulated in the scenario. Given the focus on the trading relationship impact, we concentrate on the predicted values for nodes describing the species selection and volume traded (Table 4 ). The predictions for each scenario are noted and compared between each scenario and each perspective. In this way the potential changes resulting from various fishing styles and operations can be measured directly on fish extraction.
Table 3. Scenarios and the finding values for the selected factors.

\begin{tabular}{|c|c|}
\hline Scenario & Factor findings \\
\hline $\begin{array}{l}\text { All relationship } \\
\text { cases }\end{array}$ & Aggregated findings from all the respondents \\
\hline $\begin{array}{l}\text { Patron-client } \\
\text { relationship case }\end{array}$ & $\begin{array}{l}\text { Trader BBN: Trader main activity }=\text { Trading, Degree } \\
\text { Index }=6-20 \text {, Why buy from this fisher }=50 \% \text { Put in } \\
\text { money and } 50 \% \text { Loan money and equipment } \\
\text { Fisher BBN: Agreement type }=\text { must, Fishing }=50- \\
100 \% \text {, Fished for trader to buy }=75-100 \% \text {, } \\
\text { Freelancer }=\text { no }\end{array}$ \\
\hline $\begin{array}{l}\text { Freelancer } \\
\text { relationship case }\end{array}$ & $\begin{array}{l}\text { Trader BBN: Trader main activity }=\text { Trading, Why } \\
\text { buy from this fisher }=50 \% \text { Established relationship } \\
\text { and } 50 \% \text { Other } \\
\text { Fisher BBN: Agreement type }=25 \% \text { Guarantees, } 25 \% \\
\text { fixed price, } 25 \% \text { Other, } 25 \% \text { no agreement, Fishing }= \\
50-100 \% \text {, Freelancer }=\text { yes, Fished for Trader to Buy } \\
=75-100 \%\end{array}$ \\
\hline
\end{tabular}

BBN, Bayesian Belief Network.

\section{RESULTS}

We constructed and examined a BBN for traders and fishers (Figs. 2 and 3) directly from the questionnaires (Tables $1 \& 2$ ) and network analysis (Fig. 1). The fish species specifically identified include Nile perch (NP), Nile tilapia (T), haplochromine cichlids $(\mathrm{H})$, mukene $(\mathrm{Mu})$, mamba or lungfish $(\mathrm{Ma})$, and the catfish Schilbe intermedius (Sch). In contrast to the more intense fishing practices operating in Lake Victoria (Ntara 2015) the fisher and trader lifestyles are mixed with farming and other pursuits. Only $25.2 \%$ of fishers expressed that fishing is their main occupation (Fig. 2: $25.2 \%$ probability that Fishing $=50$ to $100 \%$ ), while $29.7 \%$ of traders stated that trading is their main occupation (Fig. 3: 29.7\% likelihood that Trader Main Activity = Trading). Agriculture is the main alternative and reflects the reliance on a diverse suite of industries rather than just fish extraction. Further evidence that the fishery of Lake Nabugabo is a small scale integrated industry is that fishers often fish alone (Fig. 2: Operation $=85.5 \%$ alone ) and that traders sell dominantly to the village (Fig. 3: Market type $=27.3 \%$ Village) using a market style with the premium larger fish going to factory (Fig. 3: Why this market $=49.7 \%$ Market and $28.2 \%$ Factory). The size of the lake appears to limit the development of "camp owner" style fishing developments (Ntara 2015) and migrant fishers (Vaccaro et al. 2013). The differentiation of the fishers into freelancers and patron-clients is supported in both models (Figs. 4 and 5). The patron-client fishers are preferentially trading with a single individual as shown with the network diagram (Fig. 1). The traders who facilitate the patron-client relationship (Fig. 6) have larger loans (Loan amount $=$ average of 90,700 Ugandan Shillings), require fish for repayment (Pay back type $=$ Fish), and predominantly lend money and equipment $($ Type of capital $=63.2$ Money and 36.8 Money and boats). In contrast, the traders who engage with freelancers (Fig. 7) tend to lend smaller amounts of money (Loan Amount $=$ average of 41,400 Ugandan Shillings), require money as repayment (Pay back type $=$ Money $)$, and only lend money and not capital (Type of capital = Money).

The influence on the trader and fisher BBN models, by selecting specific findings for key nodes, enabled the inferential 
Fig. 2. Bayesian Belief Network of the fisher responses to the questionnaires showing the marginal probabilities from the all cases scenario.

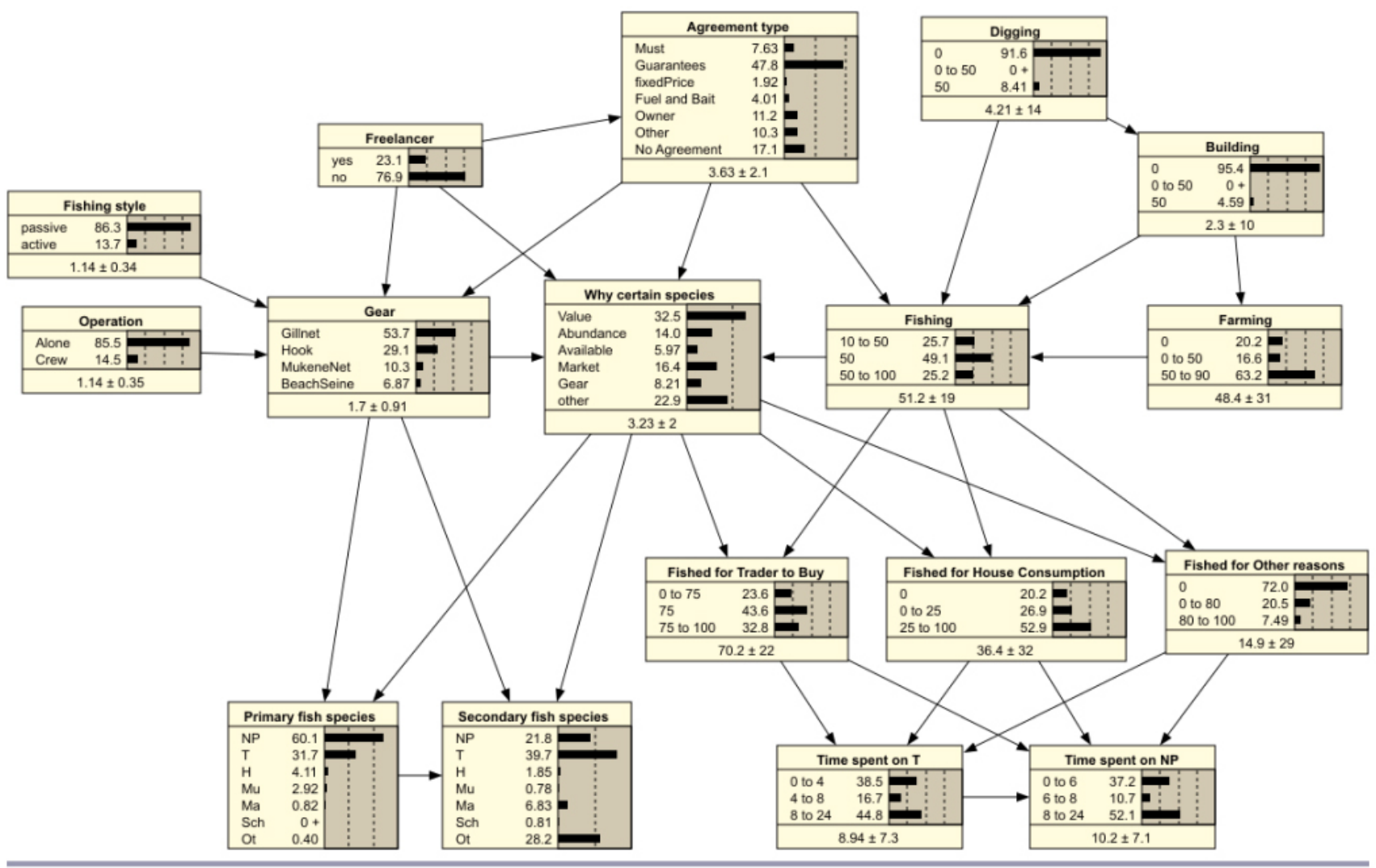

Fig. 3. Bayesian Belief Network of the trader responses to the questionnaire showing the marginal probabilities from the all cases scenario.

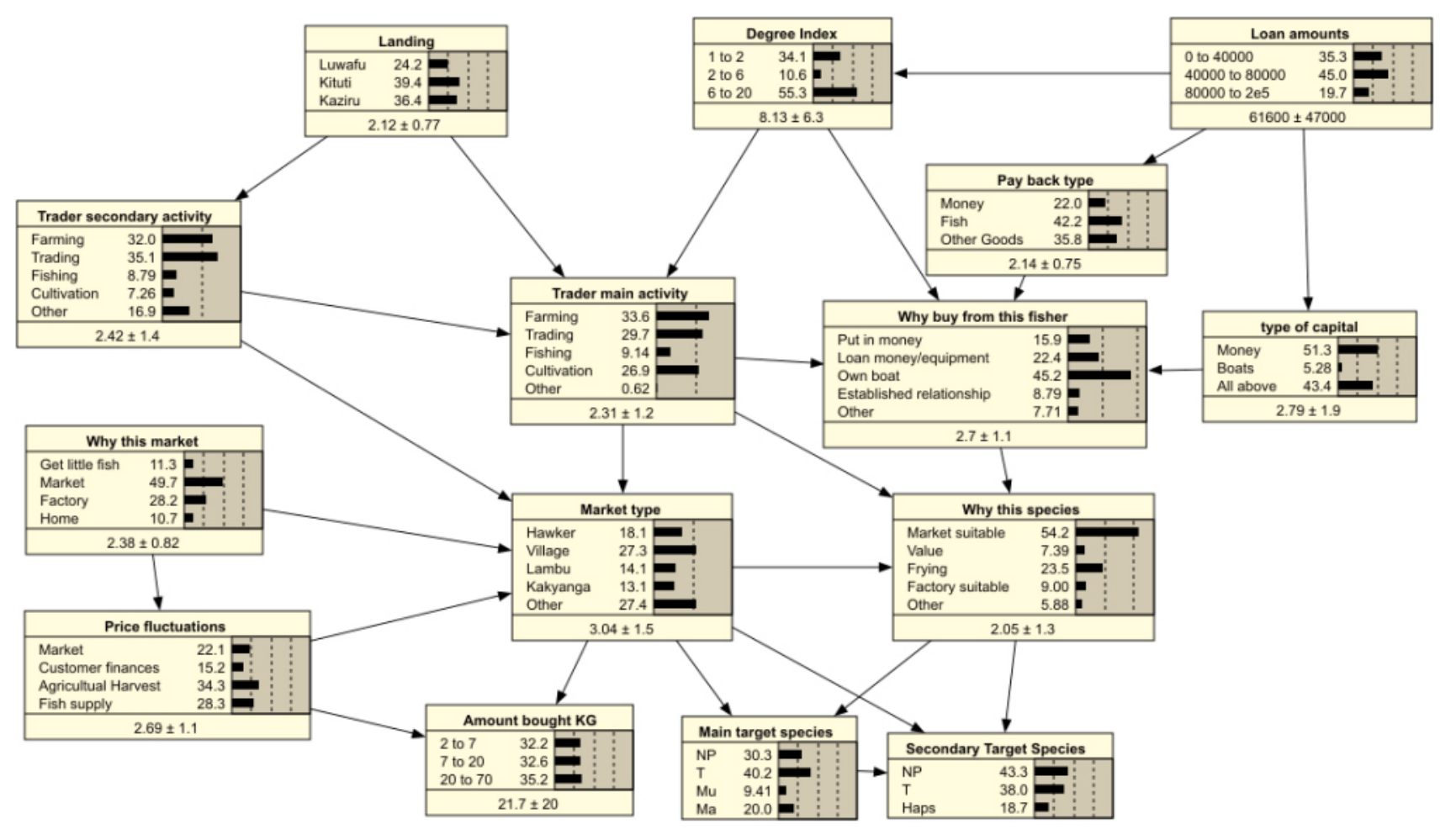


Fig. 4. Bayesian Belief Network of the fisher responses when the freelancer scenario is selected. The probabilities of the grey nodes are set at $100 \%$ for a selected category (see Table 3), while the probabilities for the remaining nodes are recalculated given the restricted probability set.

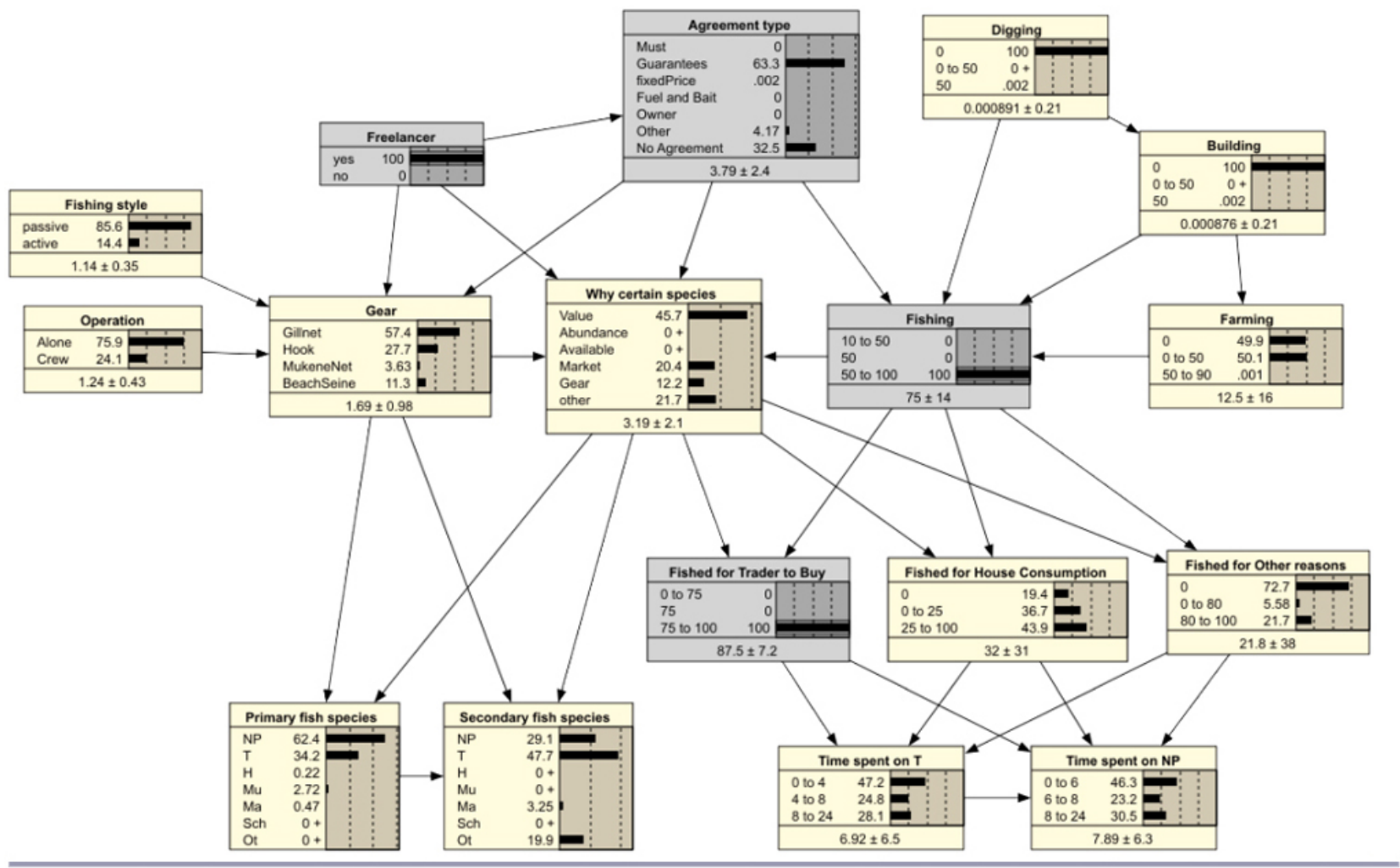

Fig. 5. Bayesian Belief Network of the fisher responses when the patron-client scenario is selected. The probabilities of the grey nodes are set at $100 \%$ for a selected category (see Table 3), while the probabilities for the remaining nodes are recalculated given the restricted probability set.

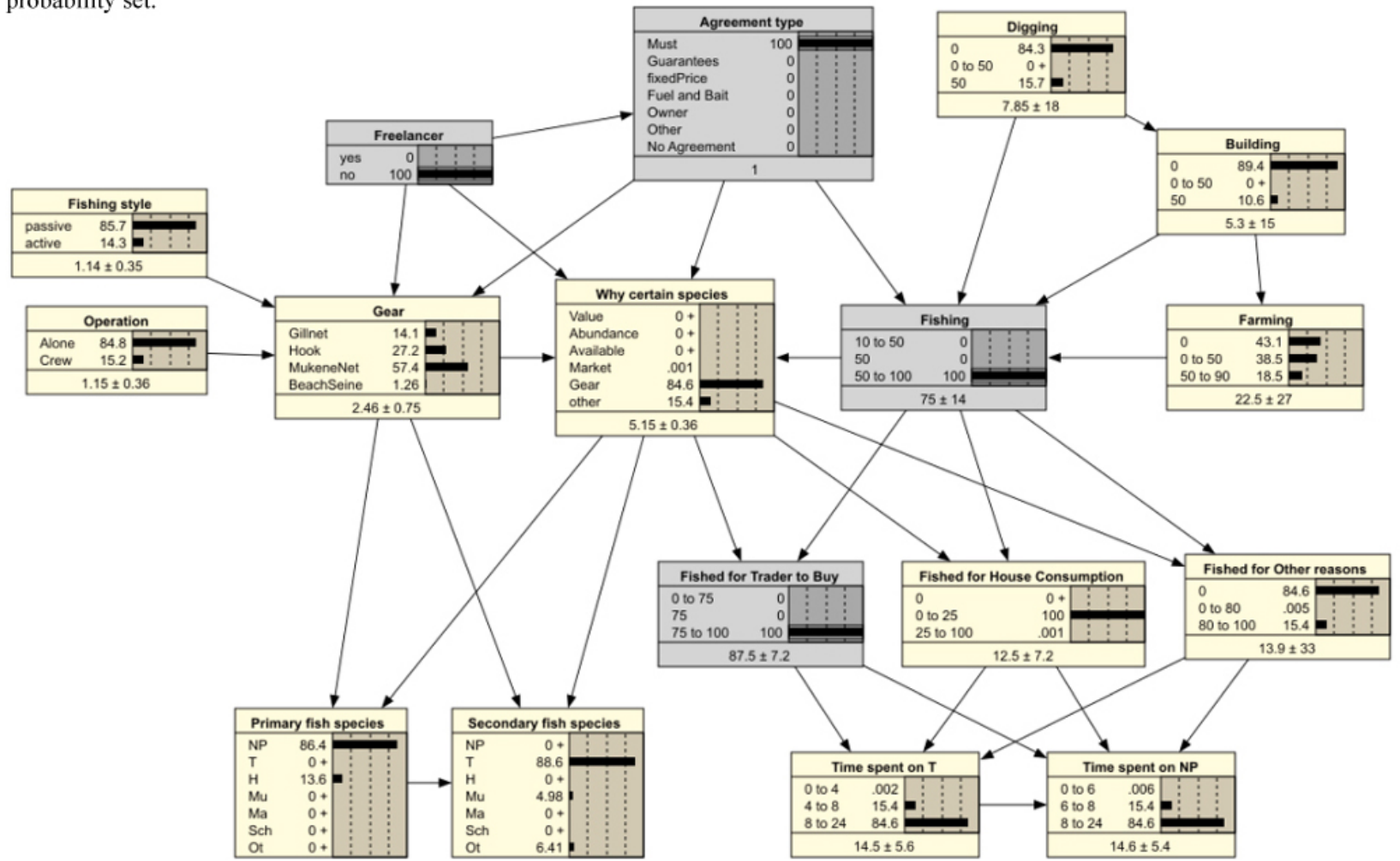


Fig. 6. Bayesian Belief Network of the trader responses when the patron-client scenario is selected. The probabilities of the grey nodes are set at $100 \%$ for a selected category (see Table 3), while the probabilities for the remaining nodes are recalculated given the restricted probability set.

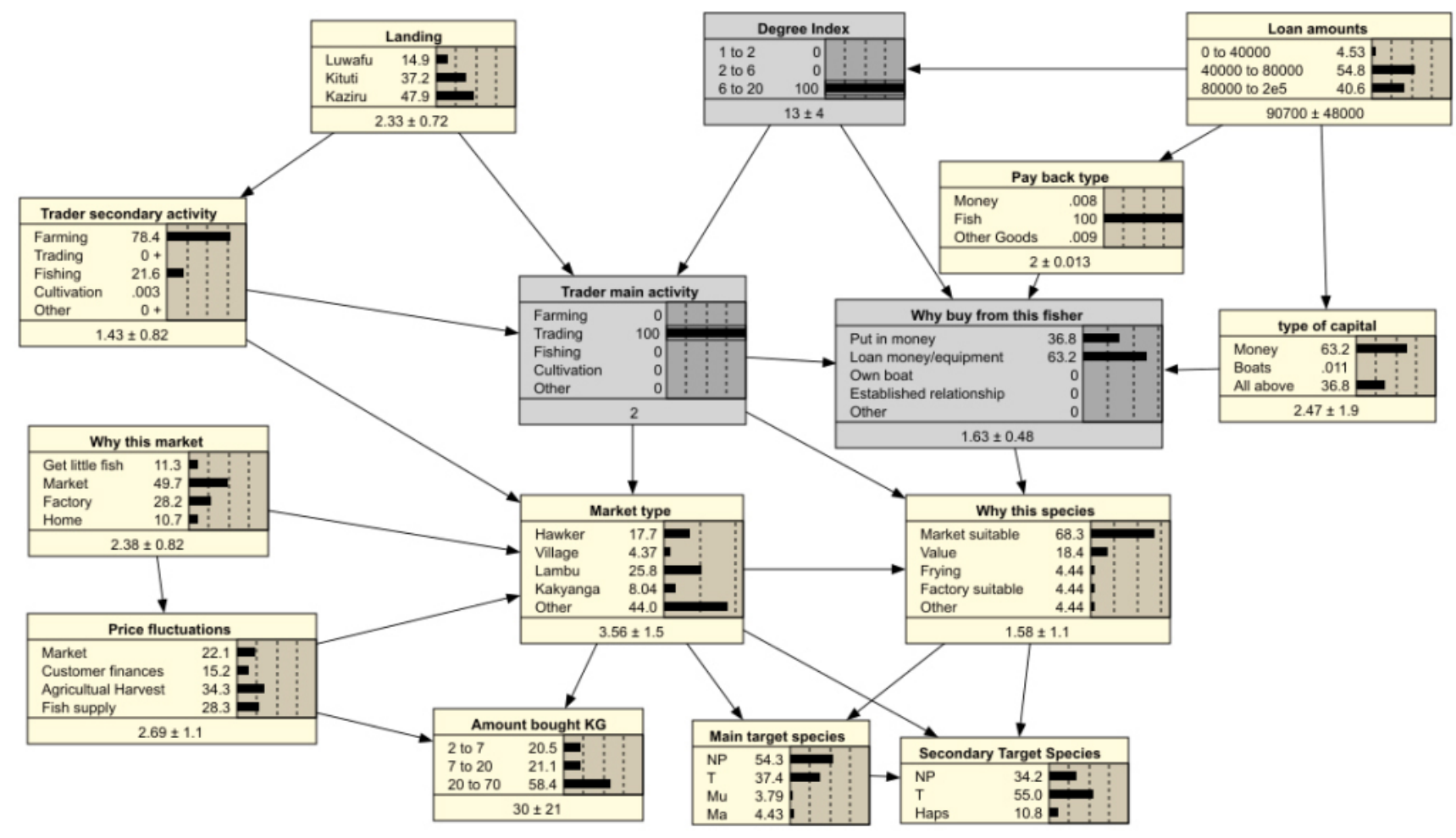

Fig. 7. Bayesian Belief Network of the trader responses when the freelancer scenario is selected. The probabilities of the grey nodes are set at $100 \%$ for a selected category (see Table 3 ), while the probabilities for the remaining nodes are recalculated given the restricted probability set.

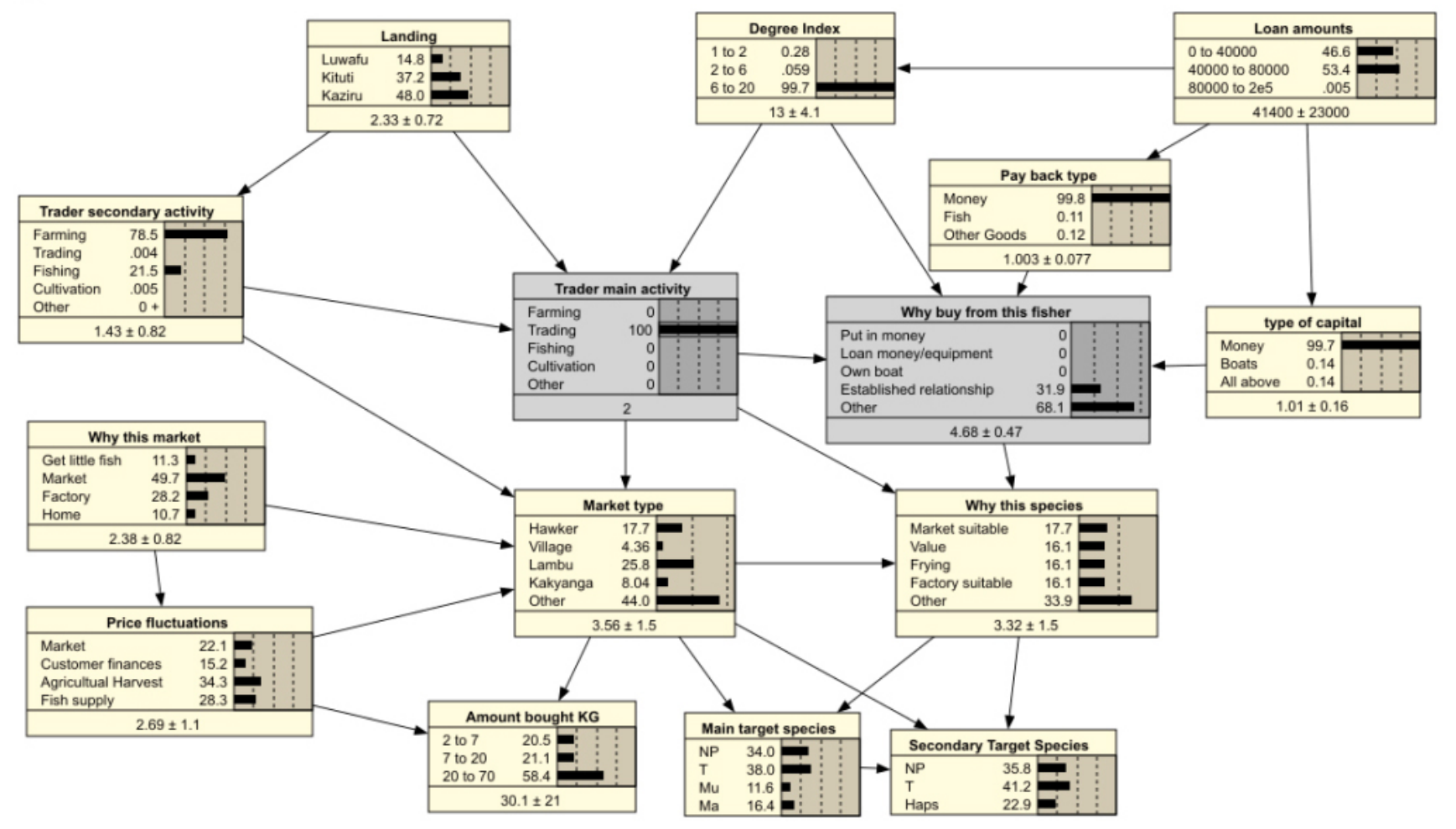


Table 4. The key output results of the scenarios listed in table 3 from the Bayesian Belief Networks.

\begin{tabular}{|c|c|c|c|c|c|c|c|}
\hline \multirow[b]{2}{*}{ Scenario } & \multicolumn{3}{|c|}{ Trader model } & \multicolumn{4}{|c|}{ Fisher model } \\
\hline & $\begin{array}{c}\text { Amount } \\
\text { bought, Avg. } \\
\mathrm{Kg}\end{array}$ & $\begin{array}{l}\text { Main target } \\
\text { species }\end{array}$ & $\begin{array}{l}\text { Secondary } \\
\text { target species }\end{array}$ & $\begin{array}{c}\text { Primary fish } \\
\text { species }\end{array}$ & $\begin{array}{l}\text { Secondary fish } \\
\text { species }\end{array}$ & $\begin{array}{c}\text { Time on Nile } \\
\text { tilapia Av.Hrs/ } \\
\text { day }\end{array}$ & $\begin{array}{c}\text { Time on Nile } \\
\text { perch Av.Hrs/ } \\
\text { day }\end{array}$ \\
\hline All cases & 21.7 & $\begin{array}{c}\text { Nile tilapia } \\
40.2 \%\end{array}$ & $\begin{array}{c}\text { Nile perch } \\
43.3 \%\end{array}$ & $\begin{array}{c}\text { Nile perch } \\
60.1 \%\end{array}$ & $\begin{array}{c}\text { Nile tilapia } \\
39.7 \%\end{array}$ & 8.9 & 10.2 \\
\hline Patron-client relationship case & 30.0 & $\begin{array}{c}\text { Nile perch } \\
54.3 \%\end{array}$ & $\begin{array}{c}\text { Nile tilapia } \\
55.0 \%\end{array}$ & $\begin{array}{c}\text { Nile perch } \\
86.4 \%\end{array}$ & $\begin{array}{l}\text { Nile tilapia } \\
\quad 88.6 \%\end{array}$ & 14.5 & 14.6 \\
\hline Freelancer relationship case & 30.1 & $\begin{array}{c}\text { Nile tilapia } \\
38.0 \%\end{array}$ & $\begin{array}{c}\text { Nile tilapia } \\
41.2 \%\end{array}$ & $\begin{array}{c}\text { Nile perch } \\
62.4 \%\end{array}$ & $\begin{array}{c}\text { Nile tilapia } \\
47.7 \%\end{array}$ & 6.9 & 7.8 \\
\hline
\end{tabular}

probabilities on the remaining nodes to be calculated (Fishers BBN: Figs. 4 and 5, Trader BBN: Figs. 6 and 7). We found that both the patron-client and freelancer relationship cases (Table 4 ) showed a likelihood of higher average fish biomass traded $(42 \%$ increase, average $=\sim 30 \mathrm{~kg}$ ) compared to the "all cases" scenario (average $=21 \mathrm{~kg}$ ). This is not particularly surprising given that the main activity selected in the scenarios was "trading," thus removing traders who purchased fish occasionally while focusing on primarily agriculture. Perhaps more interesting is that the patron-client scenario highlighted a likely narrow focus on Nile perch and Nile tilapia (54\% and 55\%, respectively, of main and secondary target species bought and $14 \mathrm{hr}$ per day fishing effort: Table 4) compared with the other scenarios $(\sim 40 \%$ of target species and $\sim 8 \mathrm{hr}$ per day fishing effort: Table 4$)$. Importantly, freelancer fishers are probably able to create responsive and flexible extraction practices (evidenced by the similar amount of fish sold by the patron-client fishers but with more diversity of species: Table 4, Fig. 4) that match market and environmental fluctuations rather than being restricted by access to gear and equipment. This can be noted by the response to the fishers question regarding "why certain species" are targeted (Fig. 4). The patron-client fishers responded (Fig. 5) by stating the reasons being Gear ( $85 \%$ likelihood) and Other (15\% likelihood), while the freelancer fishers (Fig. 4) selected Value (45\% likelihood), Market (20\% likelihood), Gear (12\% likelihood), and Other $(21 \%$ likelihood) indicating a more market driven focus.

One noticeable difference between the trader and fisher BBN model outputs was the primary fish species targeted. This difference was observed in both freelancer and patron-client scenarios. In the traders network, for all scenarios (Fig. 3), the Nile tilapia was listed as the most probable preferred main target species $(40 \%$ Nile tilapia, $30 \%$ Nile perch, $20 \%$ mamba, $9 \%$ mukene) indicating that this is the species they would desire the fishers to target. However, the fishers' most probable selection was the Nile perch ( $60 \%$ Nile perch, $32 \%$ Nile tilapia, $4 \%$ haps) as the preferred species (Table 4 ). The secondary species selection for the fishers was Nile tilapia (40\% likelihood), but the traders had equal weighting on the Nile perch and Nile tilapia $(\sim 40 \%$ likelihood). The additional emphasis by the traders on the Nile tilapia may relate to the emerging tourist market of grilled tilapia for beach establishments (Trader BBN, Patron-client scenario 'Why This Species' node = Market Suitable [68.3\%]). Given the single time period sampled by the questionnaires the BBN models were not able to provide any information regarding fishing and market trends.

\section{BBN sensitivity and predictability}

For the fisher BBN (Fig. 2), the five most influential nodes $(\%$ entropy reduction) for the "Primary fish species" node were Gear (35\%), Why these species $(29 \%)$, Secondary fish species $(21 \%)$, Fished for house consumption (11\%), and Agreement type (9\%). The most influential nodes for "Time spent on NP" were Time spent on $\mathrm{T}(24 \%)$, Fished for trader to buy $(6 \%)$, Why certain species $(5 \%)$, Fished for house consumption (4\%), and Fishing $(3 \%)$.

For the trader BBN (Fig. 3), the five most influential nodes based on the sensitivity of "Amount bought KG" node were measured and included Market type (28\%), Trader main activity (17\%), Trader secondary activity $(12 \%)$, Main target species $(6 \%)$, and Landing (5\%). The sensitivity of "Main target species" node to a finding at another node included the following five most influential nodes: Why this species $(27 \%)$, Market type $(20 \%)$, Secondary target species (17\%), Trader main activity $(5 \%)$, and Price fluctuations (4\%). There was not sufficient data within the trader $\mathrm{BBN}$ to remove $20 \%$ of the responses for independent testing of prediction accuracy.

\section{DISCUSSION}

In Lake Nabugabo, Uganda our results demonstrated that the relationship style between fishers and traders had a potential impact on extraction patterns. Although the amount of fish traded did not appreciably differ between the two fisher-trader relationship types, the targeted species and the reasons behind the fishing practices were different. Patron-client relationships that are likely to create inflexible fishing arrangements contrast to the more adaptable freelancer fishers by their narrow focus on Nile perch and Nile tilapia, both important commercial species, and in the case of Nile perch, and important export-oriented species as well (Marriott et al. 2004). In particular the patron-client fishers proffered that fish species selection was most likely based on "gear" and "other" indicating a bias towards equipment availability. The freelancer fishers conversely adapted their species selection based on "value," "market," "gear," and "other" indicating a more economic basis. Importantly only two species dominated the patron-client fisher's efforts, while the freelancer fishers were less restricted in species selection but still strongly influenced by market value. From a management perspective this suggests that the increased flexibility afforded to freelancer fishers as a result of not being locked into an asymmetrical power relationship with a patron could probably increase the ability of the fisheries system to respond to ecological dynamics if fishers 
were to switch gears, areas, or species, or exit the fishery to explore other livelihoods. However, it is clear that economic considerations of both patron-client and freelancer fishers are likely in conflict with ecological fluctuations especially if the market price does not reflect the abundance. Regional prices for Nile perch and to some extent Nile tilapia are set and isolated from fish abundance measures in Lake Nabugabo; however, the prices for smaller (nontarget) species such as haplochromine cichlids can reflect the state of the lake's resources. The BBN model used here does not explicitly explore the responsiveness of the fishers or the market to overfishing. Nonetheless sensitivity analysis of the factors influencing fish selection and intensity of fishing and trading show differences between traders and fishers. Fishers identify Gear and Species factors as the reason certain species were the focus of fishing effort. The time they spent fishing Nile perch was influenced by both the time spent fishing Nile tilapia, and if the fish were destined for the trader. Although both Nile perch and Nile tilapia can be captured in the same gillnets, the fishers targeting Nile perch use either larger mesh gillnets or longlines. Traders also stated that the species attribute and market type were most influential, while the amount of fish they bought was determined by market type and if trading was their main activity.

The dominant role of the market type influencing trader preference for particular species highlights the complicated drivers behind fisheries extraction. How this may affect lake management is a topic of general interest for many small-scale fisheries (Ntara 2015). Trade liberalization has created situations where prices are determined by factors at a scale largely removed from the ecological resource base, often influenced by the demand of distant consumers, as in the case of highly commercial exportoriented species like Nile perch observed here (e.g., Kurien 2005). This means that foreign demand creates prices that incentivize extraction despite declining fish stocks (Crona et al. 2015). At the same time a number of factors relating to the nature of both fisheries and market systems combine to effectively mask, dilute, and drown out signals from local production systems, preventing the feedback of ecological distress signals to the market (Crona et al. 2016).

The vicious cycles of increasing debt and fishing pressure related to patron-client relations among fishers and traders observed in several small-scale fisheries (Thorburn 2001, Armitage and Johnson 2006, Crona and Bodin 2010, Fabinyi 2013) led us to hypothesize that the increased flexibility (in relation to traders) of freelancer fishers could increase their ability to respond to ecological decline. It is in the context of the misalignment of market and ecological dynamics that the fisher-trader relations examined here have to be understood and analyzed.

Although freelancer fishers are not locked into a relationship with one trader and thus appear more able to change gears or even change livelihood in response to a declining fish stock, this is most likely to work in situations where ecological decline and rising costs associated with declining catch per unit effort disincentivizes continued fishing. However, the strong economic incentives provided by the prices generated by export markets (Vaccaro et al. 2013) suggest this may not be a feasible assumption. Without a force to counterbalance this influence on behavior, through rules and enforcement or provision of alternative livelihood opportunities for freelancer fishers who are not indebted (Ikiara and Odink 1999), it is unlikely that the potential flexibility of the freelancer type fishers will be turned into something beneficial for the ecological sustainability of the fishery.

Disentangling the social-ecological dynamics arising from freelancer as opposed to patron-client arrangements is challenging in that both coexist in the same system, and the relationship implications cannot be isolated in theory nor practice. One potential approach to understanding the dependencies within the system is the use of the BBN model commonly used to analyze social-ecological questionnaire data (Newton et al. 2006, Sun and Müller 2013). The power of combining qualitative and quantitative information with missing data suits the socially orientated questionnaire studies. Additionally, with sufficient data replication, the BBN can be evaluated for both prediction accuracy and sensitivity to change. For the Lake Nabugabo case the structure of the questionnaires demanded two BBNs that presented the dual perspectives of traders and fishers on a single system. The BBN model is able to infer the changes across the model domain from the finding that a specified scenario, of say the case of freelancer fishers, is observed. The benefit here is that the probability distributions present in all the nodes for the entire system remain influential despite the restricted findings in a few nodes (compare Figs. 2 and 3 to Figs. 4, 5, 6, and 7). However, the model is not able to confidently evaluate the impact on the system based on the scenario of complete structural change (e.g., to $100 \%$ freelancer fishers) because this has not been observed in Lake Nabugabo with these questionnaires. The power of the method is that scenarios that focus on a key aspect can be implemented in both models and the outcome compared.

The model developed here also included a simple network analysis as a mechanism to generate attribute data for the BBN. This method enabled a measurement of the system at a different scale from the perception of the fishers. Although a direct question regarding the trader-fisher relationship could have been asked, this might not be pertinent to the daily activities of the people of Lake Nabugabo, and indeed, it might be a foreign concept. In many respects the social construct of a freelancer or patron-client relates to the neighborhood properties of the trading system and can therefore only be determined through the analysis of the aggregated relationships in a network. The questionnaire responses were remarkably candid about delicate issues regarding lending agreements and capital arrangements, but there is likely to be a limit to the level of detail being openly declared to a researcher. Network analysis is a mechanism to resolve some of this detail by focusing on the routine transactions of fish trading.

Our comparisons between the fisher and trader model detected a likely difference in the targeted species identified by the traders and fishers. The preference by the traders for the more abundant, but less valued Nile tilapia is in contrast to the fisher's desire for Nile perch, some of which are destined for the fish landing/ markets (e.g., Lambu), where fish-freezing trucks create a link with the international export market. Although difficult to understand fully, this may relate to the style of fishing, available gear, and market response. When "abundance" is the specified reason for the species selection in the fishers' BBN, the Nile tilapia are highly preferred. However the traders strongly identified Nile 
perch as the main target species for the fishing operations under their control, and this indicates the potential higher economic return for this species. Satisfying the expanding tourism market for grilled Nile tilapia is also a potential influence on the trader's species selection. Recent increase in demands for tilapia by the local tourism industry on the shores of Lake Nabugabo (L. Chapman, personal communication) may be driving the importance of the local tilapia catch that has a market in close proximity. The traders may also be balancing the economic return of the cheaper more abundant Nile tilapia versus the more expensive but increasingly rare large Nile perch. The fishers are also required to operate with the regulatory environment established by the BMU including fishing gear restrictions etc. Although we did not examine the use of illegal fishing gear in the context of this study, the occurrence rate can be a consequence of the changes to social networks and economic return on gear investments combined with changes in food security as observed in similar small-scale fisheries elsewhere (Stevens et al. 2015). Given the small size of the fishing enterprise at Lake Nabugabo, the spatial structure of the fishing effort, and the sessile nature of the community, the level of illegal fishing is considered manageable; however, there are still many challenges facing the fishery including enforcement of fishing regulations (Odongkara et al. 2009, Lawrence and Watkins 2012, Vaccaro et al. 2013). Interestingly, BMUs were recently disbanded in Uganda, which has implications for fishery self-regulation and sustainable fish extraction.

\section{CONCLUSIONS}

The core finding of this research is that the trader-fisher relationship has an influence on the fishing practices. This impacts the management of the lake especially from within a socialecological framework. The Beach Management Units were designed to operate as self-regulating authorities especially given the representation from different sectors of the fishing industry. The findings of this research highlight that the BMUs may not have the capacity to deliver sustainable fish extraction for the local community especially if the proportion of patron-client fishers increases. The research described here does not attempt to cover all aspects of the fishing industry at Lake Nabugabo but rather focus on an aspect of fisher and trader relationship. Additional scrutiny especially in the role of women, regional trade practices, and agricultural processes would assist the overall description of the social-ecological system and complement the previous work describing the fish ecology of the lake. However, despite the inherent complexity of the Lake Nabugabo community, exploring potential pathways for fishers to reach economic independence could help reduce market driven exploitation of a limited resource.

Responses to this article can be read online at: http://www.ecologyandsociety.org/issues/responses. $\mathrm{php} / 8833$

\section{Acknowledgments:}

We particularly like to thank the Andrew Byekwaso for conducting the questionnaires and Dennis Twinomugisha for assistance with the field program. This work was partially supported by Mistra through a core grant to the Stockholm Resilience Centre, a crossfaculty research centre at Stockholm University, and the Strategic Research Programme EkoKlim at Stockholm University, McGill School for Environment Seed Grants for New Research Initiatives, and Canada Research Chair funds (LJC, CAC), and the ErlingPersson Family Foundation through Global Economic Dynamics and the Biosphere, the Royal Swedish Academy of Sciences, Sweden. We also thank the input from three anonymous reviewers to the manuscript.

\section{LITERATURE CITED}

Aalders, I. 2008. Modeling land-use decision behavior with Bayesian belief networks. Ecology and Society 13(1):16. http://dx. doi.org/10.5751/es-02362-130116

Aguilera, P. A., A. Fernández, R. Fernández, R. Rumí, and A. Salmerón. 2011. Bayesian networks in environmental modelling. Environmental Modelling \& Software 26:1376-1388. http://dx.doi. org/10.1016/j.envsoft.2011.06.004

Armitage, D. R., and D. Johnson. 2006. Can resilience be reconciled with globalization and the increasingly complex conditions of resource degradation in Asian coastal regions? Ecology and Society 11(1):2. http://dx.doi.org/10.5751/ES-01485-110102

Balirwa, J. S., C. A. Chapman, L. J. Chapman, I. G. Cowx, K. Geheb, L. Kaufman, R. H. Lowe-McConnell, O. Seehausen, J. H. Wanink, R. L. Welcomme, and F. Witte. 2003. Biodiversity and fishery sustainability in the Lake Victoria Basin: an unexpected marriage? BioScience 53(8):703-715.

Bodin, Ö., and B. I. Crona. 2008. Management of natural resources at the community level: exploring the role of social capital and leadership in a rural fishing community. World Development 36:2763-2779. http://dx.doi.org/10.1016/j. worlddev.2007.12.002

Chapman, L. J., C. A. Chapman, R. Ogutu-Ohwayo, M. Chandler, L. Kaufman, and A. E. Keiter. 1996. Refugia for endangered fishes from an introduced predator in Lake Nabugabo, Uganda. Conservation Biology 10:554-561. http://dx. doi.org/10.1046/j.1523-1739.1996.10020554.x

Chapman, L. J., C. A. Chapman, P. J. Schofield, J. P. Olowo, L. Kaufman, O. Seehausen, and R. Ogutu-Ohwayo. 2003. Fish faunal resurgence in Lake Nabugabo, East Africa. Conservation Biology 17:500-511. http://dx.doi.org/10.1046/j.1523-1739.2003.01519. $\underline{\mathrm{X}}$

Chrétien, E., and L. J. Chapman. 2016. Habitat heterogeneity facilitates coexistence of native fishes with an introduced predator: the resilience of a fish community 5 decades after the introduction of Nile perch. Biological Invasions 18:3449-3464. http://dx.doi.org/10.1007/s10530-016-1235-x

Crona, B. I., and Ö. Bodin. 2010. Power asymmetries in smallscale fisheries: a barrier to governance transformability? Ecology and Society 15(4):32. http://dx.doi.org/10.5751/ES-03710-150432

Crona, B. I., T. M. Daw, W. Swartz, A. V Norström, M. Nyström, M. Thyresson, C. Folke, J. Hentati-Sundberg, H. Österblom, L. Deutsch, and M. Troell. 2016. Masked, diluted and drowned out: how global seafood trade weakens signals from marine 
ecosystems. Fish and Fisheries 17:1175-1182. doi:10.1111/ faf.12109 http://dx.doi.org/10.1111/faf.12109

Crona, B. I., M. Nyström, C. Folke, and N. Jiddawi. 2010. Middlemen, a critical social-ecological link in coastal communities of Kenya and Zanzibar. Marine Policy 34:761-771. http://dx.doi.org/10.1016/j.marpol.2010.01.023

Crona, B. I., T. Van Holt, M. Petersson, T. M. Daw, and E. Buchary. 2015. Using social-ecological syndromes to understand impacts of international seafood trade on small-scale fisheries. Global Environmental Change 35:162-175. http://dx.doi. org/10.1016/j.gloenvcha.2015.07.006

Downing, A. S., E. Van Nes, J. Balirwa, J. Beuving, P. Bwathondi, L. J. Chapman, I. J. M. Cornelissen, I. G. Cowx, K. Goudswaard, R. E. Hecky, J. H. Janse, A. Janssen, L. Kaufman, M. A. KisheMachumu, J. Kolding, W. Ligtvoet, D. Mbabazi, M. Medard, O. C. Mkumbo, E. Mlaponi, A. T. Munyaho, L. A. J. Nagelkerke, R. Ogutu-Ohwayo, W. O. Ojwang, H. K. Peter, D. Schindler, O. Seehausen, D. Sharpe, G. M. Silsbe, L. Sitoki, R. Tumwebaze, D. Tweddle, K. E. Van de Wolfshaar, H. Van Dijk, E. Van Donk, J. C. Van Rijssel, P. A. M. Van Zwieten, J. H. Wanink, F. Witte, and W. M. Mooij. 2014. Coupled human and natural system dynamics as key to the sustainability of Lake Victoria's ecosystem services. Ecology and Society 19(4):31. http://dx.doi.org/10.5751/ ES-06965-190431

Eriksson, H., M. de la Torre-Castro, S. W. Purcell, and P. Olsson. 2015. Lessons for resource conservation from two contrasting small-scale fisheries. Ambio 44:204-213. http://dx.doi.org/10.1007/ s13280-014-0552-5

Fabinyi, M. 2013. Social relations and commodity chains: the live reef fish for food trade. Anthropological Forum 23:36-57. http:// dx.doi.org/10.1080/00664677.2012.748645

Gudimov, A., E. O’Connor, M. Dittrich, H. Jarjanazi, M. E. Palmer, E. Stainsby, J. G. Winter, J. D. Young, and G. B. Arhonditsis. 2012. Continuous Bayesian network for studying the causal links between phosphorus loading and plankton patterns in Lake Simcoe, Ontario, Canada. Environmental Science \& Technology 46:7283-7292. http://dx.doi.org/10.1021/es300983r

Ikiara, M. M., and J. G. Odink. 1999. Fishermen resistance to exit fisheries. Marine Resource Economics 14:199-213. http://dx. doi.org/10.1086/mre.14.3.42629265

Korb, K., and A. Nicholson. 2010. Bayesian artificial intelligence. Second edition. Chapman \& Hall, London, UK.

Kurien, J. 2005. Responsible fish trade and food security. Food and Agriculture Organization of the United Nations, Rome, Italy.

Lawrence, T. J., and C. Watkins. 2012. It takes more than a village: the challenges of co-management in Uganda's fishery and forestry sectors. International Journal of Sustainable Development \& World Ecology 19(2):144-154. http://dx.doi.org/10.1080/13504509.2011.606510

Marcot, B. G., R. S. Holthausen, M. G. Rowland, and M. J. Wisdom. 2001. Using Bayesian belief networks to evaluate fish and wildlife population viability under land management alternatives from an environmental impact statement. Forest Ecology and Management 153:29-42. http://dx.doi.org/10.1016/ $\underline{\mathrm{S} 0378-1127(01) 00452-2}$
Marcot, B. G., J. D. Steventon, G. D. Sutherland, and R. K. McCann. 2006. Guidelines for developing and updating Bayesian belief networks applied to ecological modeling and conservation. Canadian Journal of Journal of Forest Research 36:3063-3074. http://dx.doi.org/10.1139/X06-135

Marín, A., and F. Berkes. 2010. Network approach for understanding small-scale fisheries governance: the case of the Chilean coastal co-management system. Marine Policy 34:851-858. http://dx.doi.org/10.1016/j.marpol.2010.01.007

Marriott, A., M. Dillon, and S. Hanah. 2004. Impacts of globalisation on fish utilisation and marketing systems in Uganda. Project 8112. Department for International Development, Kampala, Uganda.

Maurice, S. 2011. Analysis of small-scale fisheries' values-chains in Uganda. Aquaculture Management Consultants Ltd., Kampala, Uganda.

Merlijn, A. G. 1989. The role of middlemen in small-scale fisheries: a case study of Sarawak, Malaysia. Development and Change 20:683-700. http://dx.doi.org/10.1111/j.1467-7660.1989. tb00362.x

Mkumbo, O. C., and B. E. Marshall. 2015. The Nile perch fishery of Lake Victoria: current status and management challenges. Fisheries Management and Ecology 22:56-63. http://dx.doi. org/10.1111/fme.12084

Newton, A. C., E. Marshall, K. Schreckenberg, D. Golicher, D. W. te Velde, F. Edouard, and E. Arancibia. 2006. Use of a Bayesian belief network to predict the impacts of commercializing nontimber forestry products on livelihoods. Ecology and Society 11 (2):24. http://dx.doi.org/10.5751/ES-01843-110224

Ntara, M. M. 2015. A social analysis of contested fishing practices in Lake Victoria. Dissertation, Wageningen University, Wageningen, The Netherlands.

Nyboer, E. A., and L. J. Chapman. 2013. Movement and home range of introduced Nile perch (Lates niloticus) in Lake Nabugabo, Uganda: implications for ecological divergence and fisheries management. Fisheries Research 137:18-29. http://dx. doi.org/10.1016/j.fishres.2012.08.003

Ogutu-Ohwayo, R. 1993. The effects of predation by Nile perch, Lates niloticus L., on the Fish of Lake Nabugabo, with suggestions for conservation of endangered endemic cichlids. Conservation Biology 7:701-711. http://dx.doi.org/10.1046/ j.1523-1739.1993.07030701.x

Odongkara, K., R. Abila, and J. Luomba. 2009. The contribution of Lake Victoria fisheries to national economies. African Journal of Tropical Hydrobiology and Fisheries 12:47-51. http://dx.doi. org/10.4314/ajthf.v12i1.57369

Paterson, J. A., and L. J. Chapman. 2009. Fishing down and fishing hard: ecological change in the Nile perch of Lake Nabugabo, Uganda. Ecology of Freshwater Fish 18:380-394. http://dx.doi.org/10.1111/j.1600-0633.2009.00355.x

Platteau, J.-P., and A. Abraham. 1987. An inquiry into quasicredit contracts: the role of reciprocal credit and interlinked deals in small-scale fishing communities. Journal of Development Studies 23:461-490. http://dx.doi.org/10.1080/00220388708422044 
Platteau, J.-Ph., and J. Nugent. 1992. Share contracts and their rationale: lessons from marine fishing. Journal of Development Studies 28:386-422. http://dx.doi.org/10.1080/00220389208422239

Pollino, C. A., O. Woodberry, A. Nicholson, K. Korb, and B. T. Hart. 2007. Parameterisation and evaluation of a Bayesian network for use in an ecological risk assessment. Environmental Modelling \& Software 22:1140-1152. http://dx.doi.org/10.1016/j. envsoft.2006.03.006

Pringle, R. M. 2005. The origins of the Nile perch in Lake Victoria. BioScience 55:780-787.

Russell, S. D. 1987. Middlemen and moneylending: relations of exchange in a highland Philippine economy. Journal of Anthropological Research 43:139-161. http://dx.doi.org/10.1086/ jar.43.2.3630222

Stager, J. C., J. Westwood, D. Grzesik, and B. F. Cumming. 2005. A 5500-year environmental history of Lake Nabugabo, Uganda. Palaeogeography, Palaeoclimatology, Palaeoecology 218:347-354. http://dx.doi.org/10.1016/j.palaeo.2004.12.025

Stelzenmüller, V., J. Lee, E. Garnacho, and S. I. Rogers. 2010. Assessment of a Bayesian Belief Network-GIS framework as a practical tool to support marine planning. Marine Pollution Bulletin 60:1743-1754. http://dx.doi.org/10.1016/j.marpolbul.2010.06.024

Stevens, K., K. A. Frank, and D. B. Kramer. 2015. Do social networks influence small-scale fishermen's enforcement of sea tenure? PLoS ONE 10:e0121431. http://dx.doi.org/10.1371/ journal.pone. 0121431

Sun, Z., and D. Müller. 2013. A framework for modeling payments for ecosystem services with agent-based models, Bayesian belief networks and opinion dynamics models. Environmental Modelling \& Software 45:15-28. http://dx.doi. org/10.1016/j.envsoft.2012.06.007

Thorburn, C. 2001. The house that poison built: customary marine property rights and the live food fish trade in the Kei Islands, southeast Maluku. Development and Change 32:151-180. http://dx.doi.org/10.1111/1467-7660.00200

Thyresson, M., B. Crona, M. Nyström, M. de la Torre-Castro, and N. Jiddawi. 2013. Tracing value chains to understand effects of trade on coral reef fish in Zanzibar, Tanzania. Marine Policy 38:246-256. http://dx.doi.org/10.1016/j.marpol.2012.05.041

Vaccaro, I., C. A. Chapman, E. A. Nyboer, M. Luke, A. Byekwaso, C. Morgan, D. Mbabazi, D. Twinomugisha, and L. J. Chapman. 2013. An interdisciplinary method to harmonise ecology, economy and co-management: fisheries exploitation in Lake Nabugabo, Uganda. African Journal of Aquatic Science 38:97-104. http://dx.doi.org/10.2989/16085914.2013.842535

Vilizzi, L., A. Price, L. Beesley, B. Gawne, A. J. King, J. D. Koehn, S. N. Meredith, D. L. Nielsen, and C. P. Sharpe. 2012. The belief index: an empirical measure for evaluating outcomes in Bayesian belief network modelling. Ecological Modelling 228:123-129. http://dx.doi.org/10.1016/j.ecolmodel.2012.01.005

Walker, B., C. S. Holling, S. R. Carpenter, and A. Kinzig. 2004. Resilience, adaptability and transformability in social-ecological systems. Ecology and Society 9(2):5. http://dx.doi.org/10.5751/ es-00650-090205
Wamukota, A., T. D. Brewer, and B. Crona. 2014. Market integration and its relation to income distribution and inequality among fishers and traders: the case of two small-scale Kenyan reef fisheries. Marine Policy 48:93-101. http://dx.doi.org/10.1016/ j.marpol.2014.03.013

Wamukota, A. W., B. Crona, K. Osuka, and T. M. Daw. 2015. The importance of selected individual characteristics in determining market prices for fishers and traders in Kenyan smallscale fisheries. Society \& Natural Resources 28:959-974. http://dx. doi.org/10.1080/08941920.2015.1014600 